\title{
Immunochemical Detection of Parathyroid Hormone-Related Protein in the Saccus Vasculosus of a Teleost Fish
}

\author{
A. J. Devlin, J. A. Danks, ${ }^{*}$ M. K. Faulkner, D. M. Power, $\dagger$ A. V. M. Canario, $\dagger$ \\ T. J. Martin, ${ }^{*}$ and P. M. Ingleton \\ Institutes of Cancer Studies and Endocrinology, The Medical School, Beech Hill Road, Sheffield S10 2RX, \\ United Kingdom; *St. Vincent's Institute of Medical Research, 41, Victoria Parade, Fitzroy, Victoria 4065, \\ Australia; and †Universidade do Algarve, Campus de Gambelas, Faro 8000, Portugal
}

September 26, 1995

Using antisera to regions of human parathyroid hormone-related protein (PTHrP) the saccus vasculosus (SV) of the sea bream (Sparus aurata) has been shown to contain immunoreactive PTHrP. By immunohistochemistry (IHC) the epithelial coronet cells in fixed and waxembedded SV tissue reacted with antisera to the prepro region of human PTHrP $(-13$ to +2$)$, the N-terminus PTHrP (1-16), and the midmolecule PTHrP (50-69). Sodium dodecyl sulfate-polyacrylamide gel electrophoresis of saccus extracts and incubation media contained two major proteins of 14.3 and $15 \mathrm{kDa}$. By Western blotting these two proteins both reacted with the three antisera used for IHC, suggesting that they are immunochemically similar to human PTHrP (1-84). Ultrastructurally the coronet cells of Sparus saccus vasculosus resembled coronet cells described for other teleosts, with an abundant smooth endoplasmic reticulum (SER) which was more highly organized in the coronets. IHC at EM level showed reaction mainly with the membranes of the SER. These results suggest that $S$. aurata saccus vasculosus may produce a PTHrP-like molecule similar to human PTHrP. @ 1996 Academic Press, Inc.

The saccus vasculosus is an organ found only in some species of teleost and elasmobranch fishes. It lies beneath the brain, posterior to the pituitary, and is composed of epithelial cells lining a lumen which is continuous with that of the third ventricle. The epithelial cells separate the lumen from a dense network of capillaries responsible for the appearance of the organ and its name. The principal epithelial cells lining the lumen are the coronet cells, together with supporting cells and cerebrospinal fluid (CSF)-contacting neurons. (Altner and Zimmerman, 1972). The coronet cells are so called because they have expanded protrusions from the luminal surface of the cell, which are expanded ends of cilia, creating a crown-like appearance. A precise function for the coronet cells has not yet been determined but ultrastructurally they contain a large proportion of smooth endoplasmic reticulum (SER), which may be concerned in lipid metabolism and production of intracellular protein (Graf von Harrach, 1970). However, Billenstein and Galer (1968) and von Mecklenburg (1973) noted the presence of cytoplasmic granules which could be secretory granules, or possibly stored glycogen. Thus protein production appears to be an important metabolic activity of coronet cells, but whether this is secreted is not clear.

The function of the saccus has been suggested to be mainly concerned with homeostasis of the cerebrospinal fluid; early studies noted changes in glycogen content of the cells, suggesting carbohydrate supply to 
brain cells (Sundaraj and Prasad, 1963). More recent studies have been concerned with a possible role in osmoregulation via the activity of ATPase enzymes involved in transport of monovalent $\left(\mathrm{Na}^{+} / \mathrm{K}^{+}\right)$and divalent $\mathrm{Mg}^{2+} / \mathrm{Ca}^{2+}$ cations (Jansen and Flight, 1969; Jansen et al., 1981, 1982). To date no specific peptide which may be concerned in control of ion regulation has been identified in saccus epithelial cells. The present study reports some initial observations that parathyroid hormone-related protein (PTHrP) is present in coronet cells of the saccus vasculosus (SV) in the sea bream (Sparus auratus).

Parathyroid hormone-related protein was first identified as the mediating factor responsible for hypercalcemia associated with certain human malignant tumors (humoral hypercalcemia of malignancy, HHM), (Moseley et al., 1987). Immunodetectable PTHrP is present in a variety of tumors, especially those of squamous cell origin (Danks et al., 1989); however, it is also found in a range of normal cells, particularly human keratinocytes (Danks et al., 1989). PTHrP can be detected in the pituitary and serum of a marine teleost, the sea bream (S. aurata), and it appears to be secreted by the pituitary in vitro (Danks et al., 1993). During the latter studies some cells of the saccus vasculosus epithelium also gave positive reactions with antiserum to PTHrP; these studies are now extended.

\section{MATERIALS AND METHODS}

The fish used in these studies were immature sea bream, weighing approximately $120 \mathrm{~g}$. They were reared in hatcheries in Faro, Portugal, in natural day length and ambient temperature between 15 and $20^{\circ} \mathrm{C}$ in gently aerated seawater.

\section{Immunohistochemistry}

Fish were sacrificed by stunning and decapitation and the brain with attached saccus and pituitary was quickly excised and fixed in sublimated BouinHollande (Kraicer et al., 1967) for 7 days. After washing for $3 \mathrm{hr}$ in tap water the fixed tissues were dehydrated through graded alcohols, cleared, and embed- ded in paraffin wax. Parasagittal sections were cut at 5 $\mu \mathrm{m}$ on a Leitz 1515 rotary microtome and mounted on slides coated with poly-L-lysine.

The primary antibodies used for these studies were polyclonal antibodies raised either in rabbits to human PTHrP(1-16) or in sheep to human PTHrP(50-69). The specificity of these antibodies for reaction with PTHrP and not PTH were confirmed by Western blotting, radioimmunoassay, and in biological assays as previously described (Danks et al., 1989, 1990, 1993).

The methods of immunohistochemistry for light microscopy were based on the technique of Sternberger (1974) and have been described in detail in Danks et al. (1989, 1990, 1993). Briefly, after dewaxing sections were rehydrated through graded alcohols, and heavy metals from the fixative removed by $1 \%$ iodine in ethanol and decolorized in 5\% sodium thiosulphate before washing in running tap water. The steps of the immune reactions consisted of blocking nonspecific reaction sites by incubation with hydrogen peroxide, then normal swine serum. Incubation with specific primary antibody for $1 \mathrm{hr}$ at room temperature was followed by incubation with secondary antibodies, and then rabbit or sheep peroxidase antiperoxidase serum and color developed by reaction with diaminobenzidine and hydrogen peroxide. Sections were dehydrated through alcohols, cleared in xylene, and mounted in piccolyte or Depex. Negative controls included nonimmune rabbit serum substituted for primary immune antibody and primary antibody blocked with PTHrP antigen with a section of normal human skin as positive control, all as described in Danks et al. (1993). Antibody to human PTH (Biogenex) was also used as described in Danks et al. (1993).

\section{Ultrastructure and Ultrastructural Immunohistochemistry}

The saccus was freshly excised from the brain, cut into two or four pieces, and fixed in Karnovsky's glutaraldehyde/paraformaldehyde fixative (Karnovsky, 1965; Ingleton and Gaitens, 1986). For TEM tissue fragments were postfixed in osmium tetroxide, dehydrated through alcohols, and embedded in e-mix (BioRad); tissues for immunolocalization of PTHrP were similarly prepared but without osmium treatment. 
Sections were cut on a Reichert Ultracut, stained with lead citrate (Reynolds, 1963) for TEM, and examined in a Phillips EM 401 electron microscope.

PTHrP was immunolocalized in saccus cells by the following protocol: sections, mounted on nickel grids, were first etched in sodium ethoxide for $20 \mathrm{~min}$ and washed in $20 \%$ ethanol and then water briefly to arrest the etching process. Nonspecific background was blocked by immersing the grids in a drop of $1 \%$ normal goat serum in $10 \mathrm{mM}$ phosphate buffer, $\mathrm{pH} 7.6$ (PBS), containing $1 \%$ bovine serum albumin (PBS/ BSA). Grids were then immersed in primary antibody (rabbit anti-human PTHrP1-16), diluted 1:50 in PBS/ BSA, overnight at $4^{\circ}$; control grids were incubated in nonimmune rabbit serum. After washing in PBS buffer for $10 \mathrm{~min}$, with gentle agitation, grids were placed on a drop of buffer containing goat antibody to rabbit immunoglobulins tagged to $10 \mathrm{n} M$ gold particles (GAR 10, Biocell) for $30 \mathrm{~min}$. After washing in PBS, sections were stained with lead citrate and examined for specific reactions.

\section{Incubation of Sea Bream Sacci Vasculosi}

Sacci were incubated for a number of days to see if immunodetectable PTHrP was released into the medium as it is from sea bream pituitaries (Danks et al., 1993). Incubations were carried out at $18^{\circ} \mathrm{C}$. Individual sea bream SVs were held on stainless steel grids in 96-well plates in contact with $80 \mu \mathrm{l}$ of Krebs-Ringer bicarbonate $(25 \mathrm{mM} \mathrm{NaHCO} ; 145 \mathrm{mM} \mathrm{NaCl} ; 8.6 \mathrm{mM}$ $\mathrm{KCl} ; 5.3 \mathrm{mM} \mathrm{CaCl} 2 ; 1.2 \mathrm{mM} \mathrm{KH} \mathrm{PO}_{4} ; 1.2 \mathrm{mM} \mathrm{MgSO}$ ) containing $0.2 \%$ glucose, $0.006 \%$ penicillin, $20 \mu \mathrm{l} / \mathrm{ml}$ amino acids $(50 \times)$ (Flow Laboratories), $10 \mu \mathrm{l} / \mathrm{ml}$ vitamins (100×) (Flow Laboratories), $10 \mu \mathrm{l} / \mathrm{ml}$ nonessential amino acids (100×) (Flow Laboratories), $0.29 \mathrm{~g} / \mathrm{li}-$ ter glutamine. The incubation medium was replaced after $24 \mathrm{hr}$ with fresh medium. Incubations then continued for a further $48 \mathrm{hr}$. Media were stored at $-70^{\circ}$ until analyzed.

\section{Electrophoresis and Western Blotting of Saccus Vasculosus Extracts and Incubation Media}

Extracts of sea bream SVs were prepared by homogenization of individual SVs in phosphate-buffered sa- line ( $\mathrm{pH} 7.6)$ containing $0.1 \%$ Triton $\mathrm{X}-100$ (60 $\mu$ l per SV). The homogenate was left on ice for $60 \mathrm{~min}$ and then centrifuged for $15 \mathrm{~min}$ at $10,000 \mathrm{~g}$. The supernatant was collected and stored at $-70^{\circ}$.

For electrophoresis aliquots (10-15 $\mu \mathrm{l})$ of the saccus extracts or incubation media were loaded onto $15 \%$ sodium dodecyl sulfate-polyacrylamide gels (SDSPAGE) and run under reducing conditions (Laemmli, 1970) together with a lane of suitable molecular weight markers. At the end of the run gels were stained with silver nitrate (Wray et al., 1981) or Coomassie blue or used for Western blotting.

For Western blotting, the separated proteins were transferred to nitrocellulose paper (NCP), using $0.1 \mathrm{M}$ Tris, $0.192 M$ glycine, $20 \%$ methanol transfer buffer. Nonspecific protein binding was blocked by immersion of NCP in TBS (1.21g/liter Tris, $8.77 \mathrm{~g} /$ liter NaCl, $0.22 \mathrm{~g} / 1 \mathrm{CaCl}_{2} ; \mathrm{pH} 8.0$ ) containing $5 \%$ nonfat milk powder for $2 \mathrm{hr}$. After a brief rinse in TBS without milk powder the NCP was incubated for $2 \mathrm{hr}$ in rabbit antiserum to human PTHrP(1-16) or PTHrP $(-13$ to +2$)$ or in sheep antiserum to human PTHrP(50-69), all diluted $1 / 50$ in PBS/BSA. To remove excess antiserum the NCP was washed five times briefly in TBS/milk and then twice in TBS only. The subsequent $60-\mathrm{min}$ incubation in either goat anti-rabbit IgG serum (Sigma) [PTHrP(1-16) and PTHrP(-13 to +2)] diluted $1 / 100$ with PBS/BSA or rabbit anti-sheep IgG serum (Nordic Immunology) [PTHrP(50-69)] also diluted 1/100 with PBS/BSA was followed by five washes with TBS/milk, two washes in TBS, and incubation in rabbit PAP (Dako Corp.) or sheep PAP (Nordic Immunology), diluted $1 / 100$, for $60 \mathrm{~min}$. After five short washes in TBS/milk and two in TBS without milk the NCP was immersed in a solution of 3,3'-diaminobenzidine $(0.5 \mathrm{mg} / \mathrm{ml})$ with hydrogen peroxide $(0.2 \mu \mathrm{l} /$ $\mathrm{ml})$ in TBS.

\section{RESULTS}

Figure 1 shows a region of the saccus vasculosus immunostained with sheep antiserum to human PTHrP(50-69). Antiserum to PTHrP(1-16) gave similar results. Localization of the PTHrP antigen can be seen in coronet cells, both in the main body of the cells 


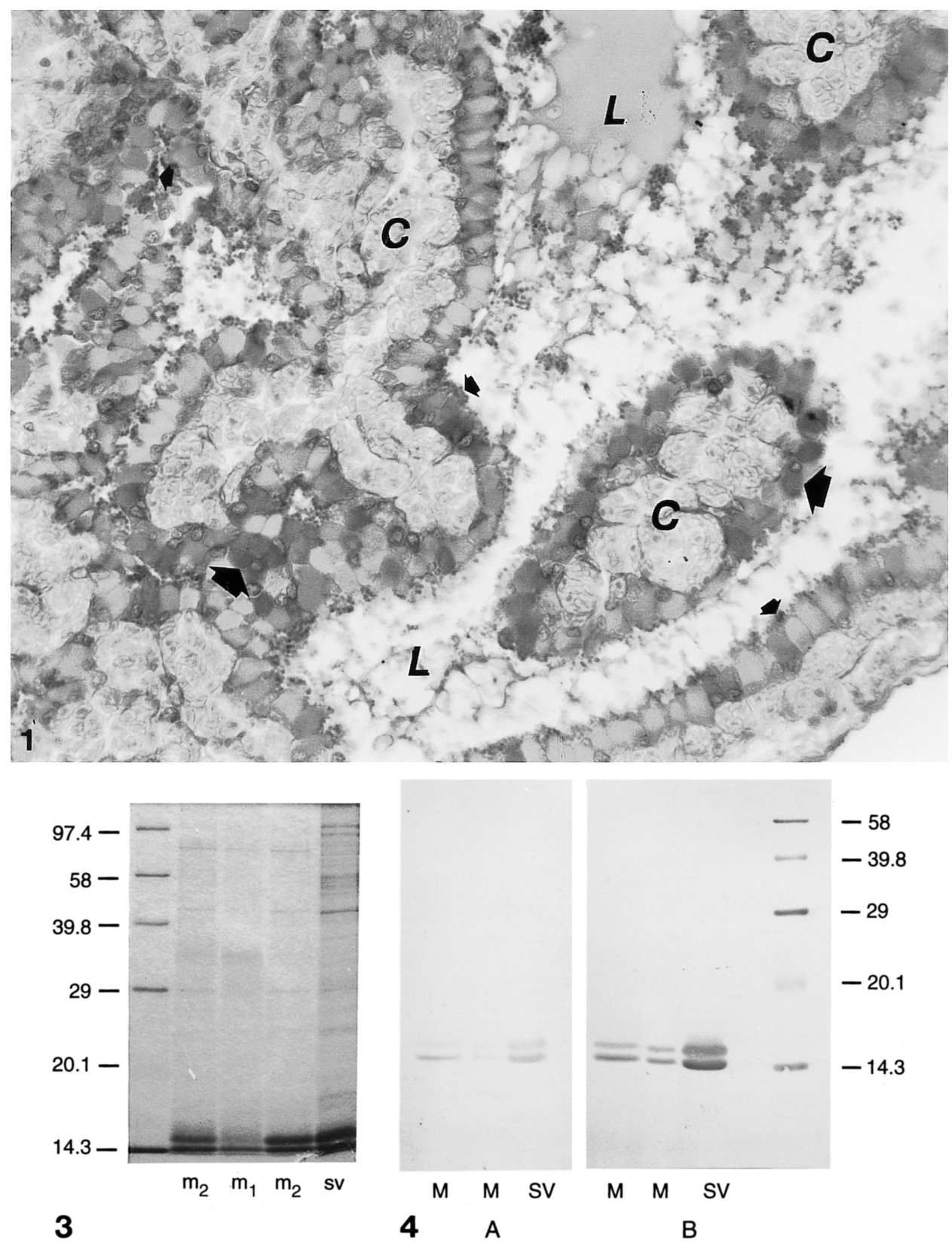

FIG. 1. Saccus vasculosus of the sea bream (Sparus aurata) immunostained with sheep antiserum to human PTHrP(50-69) and counterstained with alizarin blue. Staining occurs in some ( ) but not all of the epithelial coronet cells around the lumen (L) of the saccus and in the coronets themselves (-); there is no staining in the red blood cells of the capillaries (C).

FIG. 3. Sparus aurata saccus vasculosus extract (SV) and incubation media $\left(\mathrm{m}_{1}, \mathrm{~m}_{2}\right)$ separated by sodium dodecyl sulfate-polyacrylamide gel electrophoresis (SDS-PAGE) and stained with Coomassie blue. There are numerous protein bands but only two, of molecular weight 14.3 and $15 \mathrm{kDa}$, are present in high concentrations.

FIG. 4. Western blots of the media and tissue extracts of Sparus aurata saccus vasculosus using antiserum to (A) prepro human PTHrP (-13 to +2$)$ and (B) N-terminus PTHrP(1-16). Only the two proteins of molecular weight 14.3 and $15 \mathrm{kDa}$ reacted with the antisera. 
(large arrows) and in the coronets (small arrows); there is no reaction in the capillaries (C). It is apparent that not all the coronet cells reacted with the PTHrP antiserum. Nonimmune rabbit serum did not show any staining with the saccus tissue and primary antibody blocked with PTHrP antigen gave reduced staining (not shown). There was no reaction with antiserum to human PTH.

\section{Ultrastructure and Ultrastructural Immunohistochemistry}

Figure 2A shows the ultrastructure of the coronet cells of Sparus saccus vasculosus in which the SER is extensive, being randomly distributed in the cytoplasm of the main body of the cells but organized into parallel tubules in the coronets. Within these tubules there are electron-dense particles absent from the SER of the cell body. The coronets appear to be expanded ends of cilia of the $9+0$ organization. Using antiserum to PTHrP(1-16) Figs. $2 \mathrm{~B}$ and $2 \mathrm{C}$ show that there was immunoreaction in the epithelial coronet cells, as seen at the light microscope level; both the coronets and the main cell bodies show concentrations of gold particles. The reaction appeared to be associated principally with the membranes of the SER and not with the electron-dense particles in the lumen of tubules and vesicles of the coronets. Control reactions, using normal rabbit serum as the primary stage serum, resulted in no immunogold particles associated with coronet cells.

\section{Electrophoresis and Western Blotting}

There were several protein bands isolated by SDSPAGE of saccus extracts, but fewer in the incubation medium, with the most intense in the region of the ion front, of molecular weights approximately 14-15 kDa (Fig. 3). Two of these with molecular weights of 14.3 and $15 \mathrm{kDa}$ reacted with antisera to PTHrP. Figure 4 shows a Western blot of incubation media and saccus extract with strong immunoreaction with antiserum to human PTHrP(1-16) and weaker but clear reaction with antiserum to human $\mathrm{PTHrP}(-13$ to +2$)$; antiserum to human PTHrP(50-69) produced results similar to those with the PTHrP(1-16) antiserum (not shown), and nonimmune rabbit serum produced no reaction.

\section{DISCUSSION}

This is the first report of the detection and demonstration of a specific, potentially bioactive, hormonelike molecule in the cells of the saccus vasculosus. Confirmation of any bioactivity needs extensive physiological studies.

Ultrastructurally the coronet cells of Sparus saccus are similar to those of the stickleback (Gasterosteus aculeatus) (Follenius, 1982), of the rainbow trout (Salmo gairdneri; Oncorhynchus mykiss) (Jansen and Flight, 1969; Jansen and van Dort, 1978; von Mecklenburg, 1973), and of sunfish (Billenstein and Galer, 1968), with coronets formed from swollen closed ends of cilia $(9+0)$. The coronet cell is filled with SER, apparently randomly distributed, with distinct, well-organized Golgi regions while the coronets are filled with SER profiles forming more highly organized tubules and vesicles with electron-dense inclusion globules, most clearly visible in sections postfixed in osmium tetroxide. There appeared to be continuity between the SER of the cell and that of the coronet as described by Billenstein and Galer (1968) in the sunfish (Lepomis). These features suggest that saccus coronet cells synthesize a protein which is used intracellularly. Immunodetectable PTHrP appeared to be associated with the membranes of the SER both in the coronets and in the cells themselves. Jansen et al. (1982) localized calcium deposits in mitochondria, SER, and primary vesicles of the coronets; these lattermost they regarded as special stores additional to those normally found in mitochondria and SER.

In HHM PTHrP is considered to play an active role in mobilizing calcium stores from bone via action at the PTH/PTHrP receptor (Evely et al., 1991). In fetal sheep PTHrP is responsible, at least in part, for maintaining the differential gradient between high fetal serum calcium and that of the maternal circulation (Rodda et al., 1988; Abbas et al., 1989; Care et al., 1990). A midmolecule fragment of PTHrP was suggested to be responsible for placental transport of calcium in sheep (Care et al., 1990), a region which appeared to be present in Sparus saccus through interaction with antibody specific to the midmolecule 50-69 residues. Whether PTHrP is also functionally involved in calcium storage or mobilization in the saccus remains to be determined, but it is possible that it may be a factor 

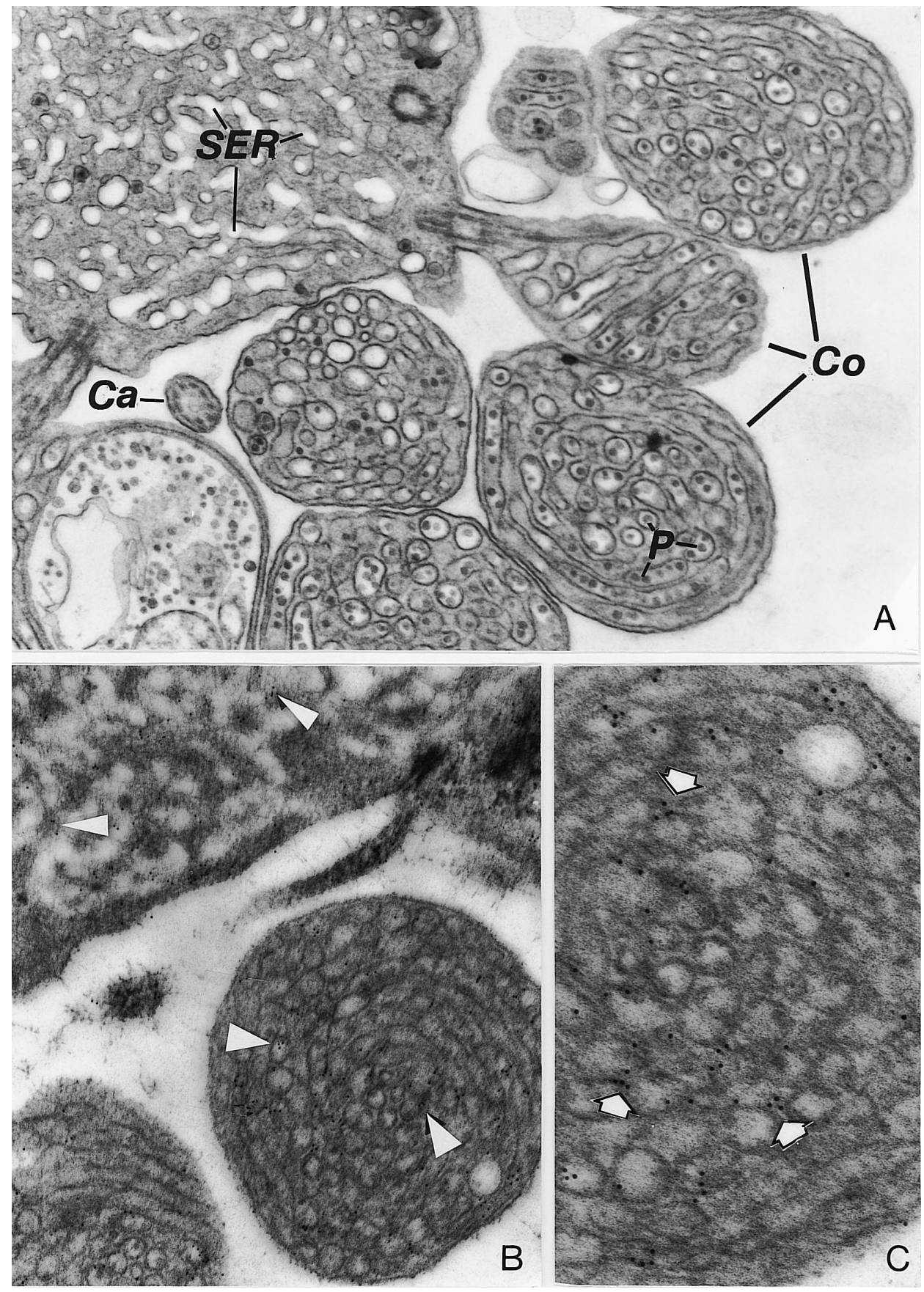

FIG. 2. (A) Electron micrograph of a coronet cell of Sparus aurata saccus vasculosus showing the abundant, randomly arranged smooth endoplasmic reticulum (SER) in the cell body. The coronets (Co) are expanded ends of cilia (Ca) with $9+0$ arrangement of internal tubules. The coronets are filled with organized arrays of SER with intraluminal electron-dense particles (P). (B) Demonstration of immunoreactive parathyroid hormone-related protein (irPTHrP) in the coronet cells of the saccus, using antibody to human PTHrP(1-16) and gold-labeled anti-rabbit immunoglobulin. Gold particles $(10 \mathrm{~nm})$ can be seen in the cell body $(\triangleright)$ and the coronet $(\triangleright)$. (C) Higher magnification of the coronet in (B) to show the gold particles ( $\triangle$ ) associated principally with the SER membranes. (A) and (C) $\times 27,000$; (B) $\times 13,500$. 
which helps to maintain calcium concentrations in the CSF within strict limits, because the lumen of the saccus is continuous with that of the third ventricle of the diencephalon of the midbrain. The epithelium of the saccus separates the lumen from capillaries, suggesting that the epithelial cells may be concerned with transport of substances between capillaries and the CSF which fills the lumen of the saccus and third ventricle. In the stickleback the coronet cells may be open to the CSF and hence take up substances from the fluid as demonstrated by Follenius (1982). Whatever the mechanism of uptake and/or exchange it is clear that the coronets of the epithelial cells create a greatly increased surface area between the cells and the luminal fluid. The difference in organization between the smooth endoplasmic reticulum of the coronets and the body of the epithelial cells suggests also that there is a specific partitioning function in the coronets. The electron-dense particles in the lumen of the coronet SER may result from accumulation of material originating from the CSF. The nature of this material is unknown and PTHrP immunoreaction appeared to be associated with the SER membrane and not the particles.

There were numerous proteins separated by SDSPAGE of SV extracts, mainly in low concentrations, but two proteins of molecular weight 14.3 and $15 \mathrm{kDa}$ were in relatively high concentrations and these reacted with antisera to regions of human PTHrP. Positive reactions with the antiserum to the prepro region of human PTHrP( -13 to +2$)$ suggest that the protein is synthesized in the saccus cells. The additional reactions with antisera specific to both $\mathrm{N}$-terminus and midmolecule regions together with the apparent molecular weight by SDS-PAGE indicate that the molecule is similar in molecular weight to human PTHrP(1-84). Moreover, because the prepro and midmolecule regions of PTHrP do not share homology with PTH, it is very unlikely that PTH is being detected by the antisera. The appearance of immunoreactive PTHrP in the incubation media after $24 \mathrm{hr}$ and a subsequent $48 \mathrm{hr}$ in fresh medium also provides some evidence that the cells may be synthesizing PTHrP. However, cells may break down during incubation and it is necessary to incubate with radioactive precursor amino acids and to detect their incorporation into the molecule to confirm the synthesis of PTHrP. The presence of PTHrP in the coronets and their cell bodies may be due to uptake from the cerebrospinal fluid as seen experimentally in the stickleback (Follenius, 1982).

These observations provide the first evidence of a potentially bioactive molecule in the saccus vasculosus of a teleost, one that may have a role in the function of the saccus vasculosus as a neurohemal periventricular organ.

\section{ACKNOWLEDGMENTS}

We are grateful to the Wellcome-Ramaciotti Fund (J.A.D.) and the Yorkshire Cancer Research Campaign (P.M.I.) for their financial support. This work was supported by EC "FAR" Grant AQ 2.458. J.A.D. is an R. D. Wright Fellow of the National Health and Medical Research Council of Australia. We thank Kevin Cork for preparation of the tissue sections for light microscopy.

\section{REFERENCES}

Abbas, S. K., Pickard, D. W., Rodda, C. P., Heath, J. A., Hammonds, R. G., Wood, W. I., Caple, I. W., Martin, T. J., and Care, A. D. (1989). Stimulation of ovine placental transport by purified natural and recombinant parathyroid hormone-related protein (PTHrP) preparations. Q. J. Exp. Physiol. 75, 549-552.

Altner, H., and Zimmerman, H. (1972). The saccus vasculosus. In "Structure and Function of Nervous Tissue" (G. H. Bourne, Ed.), Vol. V, pp. 293-328. Academic Press, New York/London.

Billenstein, D. C., and Galer, B. B. (1968). The ultrastructure of the cilia of the saccus vasculosus crown cells in the sunfish. Anat. Rec. 160, 508.

Care, A. D., Abbas, S. K., Pickard, D. W., Barri, M., Drinkhill, M., Findlay, J. B. C., White, I. R., and Caple, I. W. (1990). Stimulation of ovine placental transport of calcium and magnesium by midmolecule fragments of human parathyroid hormone-related protein. J. Exp. Physiol. 75, 605-608.

Danks, J. A., Devlin, A. J., Ho, P. M. W., Diefenbach-Jagger, H., Power, D. M., Canario, A., Martin, T. J., and Ingleton, P. M. (1993). Parathyroid hormone-related protein is a factor in normal fish pituitary. Gen. Comp. Endocrinol. 92, 201-212.

Danks, J. A., Ebeling, P. R., Hayman, J., Chou, S. T., Moseley, J. M., Dunlop, J., Kemp, B. E., and Martin, T. J. (1989). Parathyroid hormone-related protein: Immunohistochemical localisation in cancers and in normal skin. J. Bone Miner. Res. 4, 273-278.

Danks, J. A., Ebeling, P. R., Hayman, J., Diefenbach-Jagger, H., Collier, F. Mcl., Grill, V., Southby, J., Moseley, J. M., Chou, S. A. T., and Martin, T. J. (1990). Immunohistochemical localisation of parathyroid hormone-related protein in parathyroid adenoma and hyperplasia. J. Pathol. 161, 27-33. 
Evely, R. S., Bonomo, A., Schneider, H.-G., Moseley, J. M., Gallagher, J., and Martin, T. J. (1991). Structural requirements for the action of parathyroid hormone-related protein (PTHrP) on bone resorption by isolated osteoclasts. J. Bone Miner. Res. 6, 85-93.

Follenius, E. (1982). Relationship between the tubular system in the globules of the coronet cells of the saccus vasculosus and the cerebrospinal fluid in Gasterosteus aculeatus form leiurus (Teleostei). Cell Tissue Res. 224, 105-115.

Graf von Harrach, M. (1970). Elektronmikropische beobachtungen am saccus vasculosus eniger knorpelfische. Z. Zellforsch. Mikrosk. Anat. 105, 188-209.

Ingleton, P. M., and Gaitens, P. V. (1986). Prolactin cells of female rats treated with the carcinogen 7,12-dimethylbenz(a)anthracene (DMBA) in vivo. Virchows Arch. (Cell Pathol.) 51, 51-64.

Jansen, W. F., Burger, E. H., and Zandbergen, M. A. (1982). Subcellular localization of calcium in the coronet cells and tanycytes of the saccus vasculosus of the rainbow trout, Salmo gairdneri Richardson. Cell Tissue Res. 224, 169-180.

Jansen, W. F., and Flight, W. F. G. (1969). Light- and electronmicroscopical observations on the saccus of the rainbow trout. $Z$. Zellforsch. 100, 439-465.

Jansen, W. F., Flight, W. F. G., and Zandbergen, M. A. (1981). Fine structural localization of adenosine triphosphatase activities in the saccus vasculosus of the rainbow trout, Salmo gairdneri Richardson. Cell Tissue Res. 219, 267-279.

Jansen, W. F., and van Dort, J. B. (1978). Further investigations on the structure and function of the saccus vasculosus of the rainbow trout, Salmo gairdneri Richardson. Cell Tissue Res. 187, 61-68.

Karnovsky, M. J. (1965). A formaldehyde-glutaraldehyde fixative of high osmolality for use in electron microscopy. J. Cell Biol. 27, 137A.

Kraicer, J., Herlant, M., and Duclos, P. (1967). Changes in adenohy- pophyseal cytology and nucleic acid content in the rat 32 days after bilateral adrenalectomy and chronic injection of cortisol. Can. J. Physiol. 45, 947-956.

Laemmli, U. K. (1970). Cleavage of structural proteins during assembly of the head of bacteriophage T4. Nature (London) 227, 680-685.

Mecklenburg, C. von (1973). Ultrastructural changes in the coronet cells of the saccus vasculosus from rainbow trout, Salmo gairdneri (Richardson), kept in sea water. Z. Zellforsch. Mikrosk. Anat. 139, 271-284.

Moseley, J. M., Kubota, M., Diefenbach-Jagger, H., Wettenhall, R. E. H., Kemp, B. E., Suva, L. J., Rodda, C. P., Ebeling, P. R., Hudson, P. J., Zajac, J. D., and Martin, T. J. (1987). Parathyroid hormone-related protein purified from a human lung cancer cell line. Proc. Natl. Acad. Sci. USA 84, 5048-5052.

Reynolds, E. S. (1963). The use of lead citrate at high $\mathrm{pH}$ as an electron-opaque stain in electron microscopy. J. Cell Biol. 17, 208212.

Rodda, C. P., Kubota, M., Heath, J. A., Ebeling, P. R., Moseley, J. M., Care, A. D., Caple, I. W., and Martin, T. J. (1988). Evidence for a novel parathyroid hormone-related protein in fetal lamb parathyroid glands and sheep placenta: Comparisons with a similar protein implicated in humoral hypercalcaemia of malignancy. J. Endocrinol. 117, 261-271.

Sternberger, L. A. (1974). "Immunocytochemistry." Prentice Hall, Englewood Cliffs, NJ.

Sundaraj, B. I., and Prasad, M. R. N. (1963). The histophysiology of the saccus vasculosus of Notopterus chitala (Teleostei). Q. J. Microsc. Sci. 104, 465-469.

Wray, W., Boulikas, T., Wray, V. P., and Hancock, R. (1981). Silver staining of proteins in polyacrylamide gels. Anal. Biochem. 118, 197-203. 